\title{
EVOLUTION OF TRAVELLER EXPERIENCE QUALITY PERCEPTION IN EUROPEAN LEVEL POLICY DOCUMENTS AND THE CASE STUDY FOR SIAULIAI
}

\author{
Andrius Jarzemskis ${ }^{1}$, Ilona Jarzemskiene ${ }^{2}$ \\ Vilnius Gediminas Technical University, Faculty of Transport Engineering, \\ Department of Logistics and Transport Management \\ Vilnius, Lithuania, Plytines 27, Vilnius \\ landrus.jarzemskis@vgtu.lt; ${ }^{2}$ ilona.jarzemskiene@vgtu.lt
}

\begin{abstract}
EU's goal is to develop transport system which meets the economic, social and environmental requirements of society. Since first White paper on Transport in 1992 there was evolution of perception of quality and attributes of quality. The basic set of quality requirement is based on frequency, price, safety and security were dominating in 1992-2006, however since 2006 new attributes such as environment impact, and energy efficiency comes into force in European documents. However research case in Siauliai town show that it delays in user perception of quality.
\end{abstract}

Keywords: passenger, travel, quality, experience, sustainable urban mobility plan

\section{Introduction}

EU's goal is to develop transport system which meets the economic, social and environmental requirements of society. Good accessibility and safety of passenger should be provided for all European transport users, especially for elderly persons or persons with disabilities, women with children and residents in rural area. In order to do that the future trends challenges need to be considered. Moreover perception of quality differs across Europe. Passengers perceive quality of public transport based on their own perspective, culture, and tradition. Often in the Easter part of Europe public transport services are considered as worst travelling option. Up to this day, there is not clear enough what indicators should be used to measure whether particular service is of high quality or not.

The objective of this article is analysis of European level transport policy documents and strategies in order to get picture in quality perception and variables of quality. European and national related standards, studies, indicators and methodologies also reviews of previous and current European and national initiatives, strategies, policies approaches is analysed to define state of the art in passenger transport service quality monitoring and evaluation.

In order to foster sustainable mobility and improve passengers experience European Commission launched wide initiative to promote cities and towns to prepare Sustainable Urban Development Plans (SUMP's). It was highlighted in White Paper (2011). The guidelines for Developing and Implementing a Sustainable Urban Mobility Plan were prepared in 2013. Common guidelines are set for all European cities. Currently 18 cities and towns of various sizes in Lithuanian are preparing SUMPs. The passenger experience and quality perception is an important part of the SUMP's. It causes different attitudes and expectations of citizens across Europe. The results of survey made for Siauliai town SUMP illustrate the perception of quality in small to middle size towns in Lithuania.

The analysis of literature is presented in Chapter 2. Methodology is presented in Chapter 3. The main research results and finding lay in Chapter 4. Conclusions and discussion of further research are summarized in Chapter 5.

\section{Literature Review}

To answer specific problems of quality in urban public transport the QUATTRO consortium developed the European project "Instruments to implement quality in urban public transport and their impact in solicitations and contracts" (1996 - 1998).

It contributes to solve two questions:

- How to define service quality in public transport. 
- How to include and to promote quality concept in public tenders and contracts to increase effectiveness.

With the results of this Project, the European Committee of Standardization CEN elaborated the UNE-EN 13816 about quality in transport. This standard defines quality of service, objectives and measurements in public passenger transport. It contents some elements that provide an adequate reference at international level.

The propose aim of the standard is to improve passenger satisfaction level. It sets the "common framework" to define the quality of service in public passengers transport and it contemplates includes two points of view: Administration (service holder) and operators (service provider) point of view and user point of view (currents and potentials). In the next figure, "quality cycle" is explained by the UNEEN 13816, to manage the quality of service (Fig. 1).

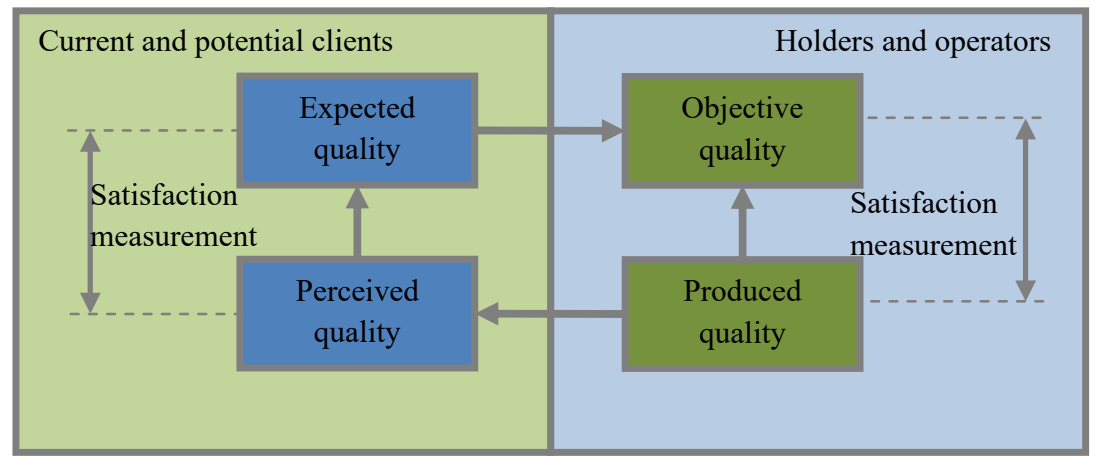

Figure 1. Quality cycle according to UNE-EN 13816

Expected quality is the level of quality advanced by user and it can be defined in terms of previsions. Objective quality is the level of quality that holders and operators want to offer. Produced quality is the level of quality acquired in the daily operations, defined by its impact in clients. It also includes service interruptions. Perceived quality is the level of quality perceived by passengers during the journey. It depends on their previous experiences with the service and with other services, on the information received, on their personal environment.

Diana and Daraio (2013) have reviewed among other things the indicators that have been proposed in the transport economics and engineering scientific literature to assess quality aspects in public transport systems in different countries, both in Europe and overseas. This review only considers variables and indicators related to physical, or instrumental measures, thus not taking into account other methods that are for example based on individual satisfaction levels, subjective or perceived quality. According to their review, the quality indicators available in the published research in these fields can be grouped as follows:

- On-time performance that is related to the service reliability. This seems the quality aspects being most considered in the above defined research field, and a lot of indicators have been proposed that are related to this aspect.

- Service coverage and availability, that identifies to which extent the studied system is available both in spatial and in temporal terms. Spatial and temporal availability can typically be measured through the consideration of the service are on one hand, of the hours of operations on the other. This is also useful to assess the importance and the impact of a service within the whole transport system. Given the broad range of implications of such quality aspects, also in this case many indicators are available in the published literature that is listed in Diana and Daraio (2013).

Other quality aspects that are equally important compared the above, but for which there is an accrued consensus on the indicator that should be adopted. The following four were clearly identified: commercial speed, walking time to/from the public transport service points, percentage of transfer passengers over the total number of passengers, ratio between passengers transported and total number of passengers.

Pticina (2011) reviews common quality indicators of urban public transport systems and identifies 8 quality components: availability (e.g, network, timetable), accessibility (e.g. interface, ticketing), information, time (e.g. speed, punctuality), customer care, comfort, safety and security, and environment (e.g. pollution) and in (Pticina and Yatskiv, 2015) the urban public transport system quality index using the analytical hierarchy process was developed.

The annual satisfaction web-survey conducted by the international bus benchmarking group (Trompet et al., 2013) allows identifying service aspects to which passengers attach high importance but report low level of satisfaction. These areas have potential room for improvement and should be prioritized. 
Axtell et al. (2008), Cavana et al. (2007) review the passenger quality perception criteria in railway transport with focus to tolerance. Choice of transport mode as expression of quality satisfaction is analysed in Carrasco et al. (2005), Kahneman (2000). Travel time savings as quality criteria is well defined by Ettema and Verschuren (2010), Hensher et al. (2003), Hess et al. (2005), Lyons et al. (2007).

\section{Methodology}

Following research methods were used to compose the article:

- Desk research is a research technique which is mainly acquired by researcher sitting at a desk collecting data from existing resources. This method is highly effective if person responsible possesses proper knowledge of how the research should be performed and what information resources are to be used. Desk research is necessary to be conducted in starting phase of research project as it is quite quick method to acquire basic information on state of the art of the research object and to benchmark further research process.

- Survey in Siauliai town conducted during preparation of Sustainable urban mobility plan in December 2016 - February 2017. The target group was inhabitants of Siauliai town and suburb areas. The questionnaire was defined in order to identify modal split, average duration of travel, main origin - destination pairs, reasons of travel mode selection, mobility satisfaction criteria's and expectations.

Following information resources were used to compile article:

- Primary data - respondents of the survey.

- Online Desk Research - incredible amount of data is available online on the internet. It is important to choose reliable information sources as there are billions of pages available on the internet. Results were gathered by using search engines;

- Research paper database research - dedicated scientific databases were browsed using relevant keywords to identify scientific approach to methodology of passenger transport quality evaluation;

- Government institutions published data - passenger transport and transport policy dedicated websites published by EU or national government bodies were analysed, as they publish reliable, official research reports, activity reports, latest versions and evaluations of policy paper and other relevant data.

- Library assembling - strategic papers, research reports, methodologies and other papers (or links to information if papers are not available for download) obtained during desk research are gathered.

\section{Research Results}

The evolutions of quality perception in European documents are presented in Chapter 4.1. The Siauliai town citizen's survey outcomes are presented in Chapter 4.2.

\subsection{Evolution of quality perception in European documents}

An analysis of EU strategies regarding passenger transport is summarized in current section of the article. European Union vision and further direction of the union is outlined in a number of different legal acts, initiatives, strategies, policies and other approaches (e.g. European Commission communications). All of these mentioned documents vary in their level of impact, terms and content, e.g. a broad understanding and agreements of EU future are set in strategies like "Europe 2020", non-mandatory recommendations in communications, while more concrete initiatives are found in Green and White papers on transport.

Analysis of mentioned documents was carried out to outline general picture of European Union strategy regarding passenger transport: some of the analysed documents are dedicated to transport in general, while other are more specific and regulate freight or passenger transport. Following documents were identified as most relevant in the context of passenger quality experience:

- White paper 1992 The future development of the common transport policy;

- European Commission Communication 1998 Developing the citizens network;

- White paper 2001 - European transport policy for 2010: time to decide;

- European Commission Communication 2006 Keep Europe moving - sustainable mobility for our Continent;

- Green paper 2007 Towards a new culture for urban mobility (presented by the Commission); 
- Action Plan on Urban Mobility 2009, Action Plan on Urban Mobility - State of Play 2012;

- European Commission Communication 2009 A sustainable future for transport: Towards an integrated, technology-led and user;

- White paper 2011 (Roadmap to a Single European Transport Area - Towards a competitive and resource efficient transport system);

- European Commission Communication 2011 A European vision for Passengers: Communication on Passenger Rights in all transport modes.

Description containing most important aspects of each of the above listed documents is presented in the tables below.

Table 1. The most important aspects of White paper on transport

\begin{tabular}{|c|c|}
\hline Document name & White paper 1992 The future development of the common transport policy \\
\hline $\begin{array}{l}\text { Most important aspects } \\
\text { regarding passenger transport }\end{array}$ & $\begin{array}{l}\text { - Improvement in the functioning, quality of transport systems including safety, reliability and } \\
\text { passenger comfort; } \\
\text { - development of transport infrastructure; } \\
\text { - improvement of transport safety; } \\
\text { - creating common transport system to increase competitiveness (liberalisation of transport } \\
\text { market); } \\
\text { - citizens and enterprises should have access to means of mobility corresponding as closely as } \\
\text { possible in quality and performance to their needs and expectations; } \\
\text { - strengthening social and economic cohesion and ensuring equal access to the transport system. }\end{array}$ \\
\hline $\begin{array}{l}\text { Identified properties or } \\
\text { indicators }\end{array}$ & $\begin{array}{l}\text { - Flexibility; } \\
\text { - Speed; } \\
\text { - Reliability; } \\
\text { - Frequency; } \\
\text { - Price; } \\
\text { - } \text { Passenger rights; } \\
\end{array}$ \\
\hline
\end{tabular}

White paper on transport (1992) was the first strategic document ever to define future of European transport and set common goals. The paper was more oriented towards freight transport rather than passenger transport; however basic definition of passenger trip quality was described using indicators (flexibility, speed, reliability, frequency and price). Passenger rights and safety were regarded as necessity instead of option. This paper also described transport user groups with special needs emphasizing users with limited mobility as vulnerable group.

Table 2. The most important aspects of EC COM 1998 Developing the citizens network

\begin{tabular}{|c|c|}
\hline Document name & European Commission Communication 1998 Developing the citizens network \\
\hline $\begin{array}{l}\text { Most important aspects } \\
\text { regarding passenger } \\
\text { transport }\end{array}$ & $\begin{array}{l}\text { - promoting use of public transport service (to reduce use of private cars); } \\
\text { - benchmarking of service performance to enable comparison of service performance; } \\
\text { - establishing political and legal framework to promote use of intellectual transport systems } \\
\text { providing real time information; } \\
\text { - } \quad \text { optimising use of current transport system. }\end{array}$ \\
\hline $\begin{array}{l}\text { Identified properties or } \\
\text { indicators }\end{array}$ & $\begin{array}{l}\text { - integration; } \\
\text { - } \text { accessibility; } \\
\text { - } \text { flexibility (responsiveness to changing transport needs); } \\
\text { - } \quad \text { real time information availability. }\end{array}$ \\
\hline
\end{tabular}

Basic indicators defined in the list changed very little in further decades, although additional indicators appeared.

Table 3. The most important aspects of White paper 2001

\begin{tabular}{|c|c|}
\hline Document name & White paper 2001 - European transport policy for 2010: time to decide \\
\hline $\begin{array}{l}\text { Most important aspects } \\
\text { regarding passenger transport }\end{array}$ & $\begin{array}{l}\text { - increasing safety, quality of services and protection of passenger rights in the railway network; } \\
\text { - encouraging development of rapid passenger transportation in TEN-T network; } \\
\text { - increased road transport safety; } \\
\text { - ensuring passenger rights in air transport and expanding passenger right protection to other } \\
\text { modes of transport; } \\
\text { - development of satellite navigation system (Galileo) to ensure accuracy, reliability and } \\
\text { security of service to the users. }\end{array}$ \\
\hline
\end{tabular}




\begin{tabular}{|l|l|}
\hline Identified properties or & - safety; \\
indicators & - compensation for delays or operators failure to meet obligations; \\
& - user rights (ensuring level of air transport users in other modes of transport); \\
& - transparency; \\
\hline - territorial cohesion; \\
- air transport service quality indicators: transparency, punctuality, number of passengers denied \\
boarding, baggage loss levels; \\
- public transport service quality indicators: \\
- basic quality criteria (health and safety of passengers, accessibility of services, level and \\
transparency of fares); \\
- advanced quality of service criteria (frequency, punctuality of services, availability of seats, \\
preferential fares for certain categories of users, information availability, reliable information \\
availability).
\end{tabular}

White paper on transport released in 2001 set first guidelines on what "quality of transport service" is providing sample quality indicators. Indicators are presented as a two level system: first level - basic quality indicators - is general availability of safe transport service for everyone. In this case aspects of journey that are necessary to get from point A to point B are regarded and the experience of journey itself is not measured. Second level of indicators is presented as a benchmarking system to increase passenger experience and attractiveness of public transport. These advanced indicators describe journey features that that are not absolutely necessary to complete a trip from point $\mathrm{A}$ to point $\mathrm{B}$, but increase passenger satisfaction with service.

Table 4. The most important aspects of communication Keep Europe moving - sustainable mobility for our Continent

\begin{tabular}{|l|l|}
\hline Document name & $\begin{array}{l}\text { European Commission Communication 2006 Keep Europe moving - sustainable mobility for } \\
\text { our Continent (Mid-term review of the European Commission's 2001 Transport White Paper). }\end{array}$ \\
\hline $\begin{array}{l}\text { Most important aspects } \\
\text { regarding passenger } \\
\text { transport }\end{array}$ & \begin{tabular}{l} 
- Availability of affordable and high-quality transport solutions; \\
\hline $\begin{array}{l}\text { Identified properties or } \\
\text { indicators }\end{array}$
\end{tabular} \\
& $\begin{array}{l}\text { - Safety; } \\
\text { - Security; }\end{array}$ \\
& - Environmental impact; \\
\hline
\end{tabular}

Communication Keep Europe moving - sustainable mobility for our Continent outlined necessity of affordable transport services: affordability was added to basic accessibility indicators.

Table 5. The most important aspects of Green paper 2007 on urban mobility

\begin{tabular}{|c|c|}
\hline Document name & Green paper 2007 Towards a new culture for urban mobility (presented by the Commission) \\
\hline $\begin{array}{l}\text { Most important aspects } \\
\text { regarding passenger transport }\end{array}$ & $\begin{array}{l}\text { - Achieving better urban and suburban mobility, sustainable mobility, and mobility for all the } \\
\text { inhabitants of Europe; } \\
\text { - Promotion of co-modality - citizens should be able to optimise their travel through efficient } \\
\text { links between the different modes of transport; } \\
\text { - Increasing availability of traffic and travel data, assistance and dynamic control of transport to } \\
\text { travellers, drivers (including Galileo service); } \\
\text { - Advanced collective transport ticketing systems, connected by data exchange protocols for } \\
\text { better integrated ticketing; } \\
\text { - Creating and promoting intelligent payment systems that should use smart cards, interoperable } \\
\text { between transport modes, between various functions (such as transport-related payments, non- } \\
\text { transport services, parking, and customer loyalty schemes), between areas and, in the longer } \\
\text { term, between countries. Possibilities for differentiated tariffs according to time or target group } \\
\text { (for example peak/off-peak) could be part of the system; } \\
\text { - Urban infrastructure, including roads, cycle paths etc., but also trains, buses and public spaces, } \\
\text { parkings, bus stops, terminals, etc., should be of high quality; } \\
\text { - People with accessibility issues should have easy access to urban transport infrastructure; } \\
\text { - Efficient connections inside towns and cities, connecting cities with the surrounding region, } \\
\text { between the urban and interurban networks, and with the Trans-European Transport Networks } \\
\text { (TEN-T) are also essential; } \\
\text { - Good connections to airports, railway stations and ports are of particular importance to } \\
\text { interconnect the different modes of transport; } \\
\text { - European Commission should promote less costly collective transport solutions, such as bus } \\
\text { rapid transit, as an alternative to the more expensive tram and metro systems. }\end{array}$ \\
\hline
\end{tabular}




\begin{tabular}{|l|l|}
\hline Identified properties or & - Availability of user-friendly, adequate and interoperable multi-modal trip information for \\
indicators & planning a journey; \\
& - Accessibility of urban transport; \\
- Public transport quality basic indicators (quality, efficiency and availability); & - Public transport quality advanced indicators (frequency, quickness, reliability, comfort); \\
& - Flexibility; \\
& - Journey duration (public transport travel times should be at least as short as using personal car); \\
& - Qualified staff; \\
\hline
\end{tabular}

Green paper 2007 on urban mobility provided extended description of transport users with limited mobility including not only disabled and elderly passengers, but also families with young children and children themselves as a user group. Additional user group of tourists was identified and setting different quality standards taking into account needs of tourists was suggested. Real time travel information necessity was emphasized in urban travel.

Table 6. The most important aspects of Action Plan on Urban Mobility 2009, Action Plan on Urban Mobility - State of Play 2012

\begin{tabular}{|l|l|}
\hline Document name & Action Plan on Urban Mobility 2009, Action Plan on Urban Mobility - State of Play 2012 \\
\hline $\begin{array}{l}\text { Most important aspects } \\
\text { regarding passenger }\end{array}$ & - Raising awareness on environmental impact of travelling; \\
transport & - Strengthening passenger rights in urban public transport; \\
& - Issues with lack of quality indicators addressed. \\
\hline $\begin{array}{l}\text { Identified properties or } \\
\text { indicators }\end{array}$ & - Noise level; \\
& - Pollution; \\
\hline
\end{tabular}

Action Plan on Urban Mobility 2009 sets focus on urban transport systems both from citizen and user view: citizens suffer from impact of urban transport, such as pollution, noise, congestion, sustainable energy use which are not directly considered as service quality indicators, however impact reduction measure do impact service and service quality for the end users. This document is the first one to bond citizens and users points of view on quality: transport user is to be informed on impact his/hers choices have on own and other citizens' health.

Table 7. The most important aspects of European Commission Communication 2009 A sustainable future for transport: Towards an integrated, technology-led and user

\begin{tabular}{|c|c|}
\hline Document name & $\begin{array}{l}\text { European Commission Communication } 2009 \text { A sustainable future for transport: Towards an } \\
\text { integrated, technology-led and user }\end{array}$ \\
\hline $\begin{array}{l}\text { Most important aspects } \\
\text { regarding passenger transport }\end{array}$ & $\begin{array}{l}\text { - Social and economic cohesion through transport (including TEN-T network development); } \\
\text { - Quality service for transport promoted by strengthening passenger rights (air transport, rail } \\
\text { transport, maritime transport and coach); } \\
\text { Emphasis on ageing society: ageing citizens have higher standards on the provision of } \\
\text { transport services involving a high level of perceived security and reliability, and also expect } \\
\text { appropriate solutions for users with reduced mobility; } \\
\text { - Due to aging society, transport service provisions costs are to increase (lack of labour force, } \\
\text { costs of ensuring quality and accessibility of service); } \\
\text { - Mobility of workers in EU is expected to increase; } \\
\text { - Better integration of the different modes of transport as a way to improve the overall } \\
\text { efficiency of the system and the acceleration of the development and deployment of } \\
\text { innovative technologies - within an approach that always keeps the transport users and } \\
\text { workers, with their needs and rights, at the centre of policymaking; } \\
\text { - Promotion of environmentally friendly public transport solutions and modal shift; } \\
\text { - Use of ITS to integrate different modes of transport and ensure seamless travel experience; } \\
\text { Integrated urban transport planning to create efficient transport systems considering other } \\
\text { connected policies and urban infrastructure elements. }\end{array}$ \\
\hline $\begin{array}{l}\text { Identified properties or } \\
\text { indicators }\end{array}$ & $\begin{array}{l}\text { - Safety; } \\
\text { - Security; } \\
\text { - Passenger rights; } \\
\text { - Safety (in context of climate change and extreme weather events); } \\
\text { - Personal security; } \\
\text { - Accessibility; } \\
\text { - Privacy and data protection issues that can arise in relation to the means employed for } \\
\text { - Surveillance, registration and control purposes; } \\
\text { - Sustainability. }\end{array}$ \\
\hline
\end{tabular}


In context of other analysed documents, EC Communication Action Plan on Urban Mobility 2009 addressed new issues and trends in field of passenger transport: privacy and information security of passengers, effects of extreme weather on transport systems, special emphasis on ageing society, mobility of labour force within EU and importance of sustainable passenger transport solutions (reducing dependency on fossil fuel, environmental impact).

Table 8. The most important aspects of White paper 2011 (Roadmap to a Single European Transport Area - Towards a competitive and resource efficient transport system)

\begin{tabular}{|c|c|}
\hline Document name & $\begin{array}{l}\text { White paper } 2011 \text { (Roadmap to a Single European Transport Area - Towards a competitive and } \\
\text { resource efficient transport system) }\end{array}$ \\
\hline $\begin{array}{l}\text { Most important aspects } \\
\text { regarding passenger transport }\end{array}$ & 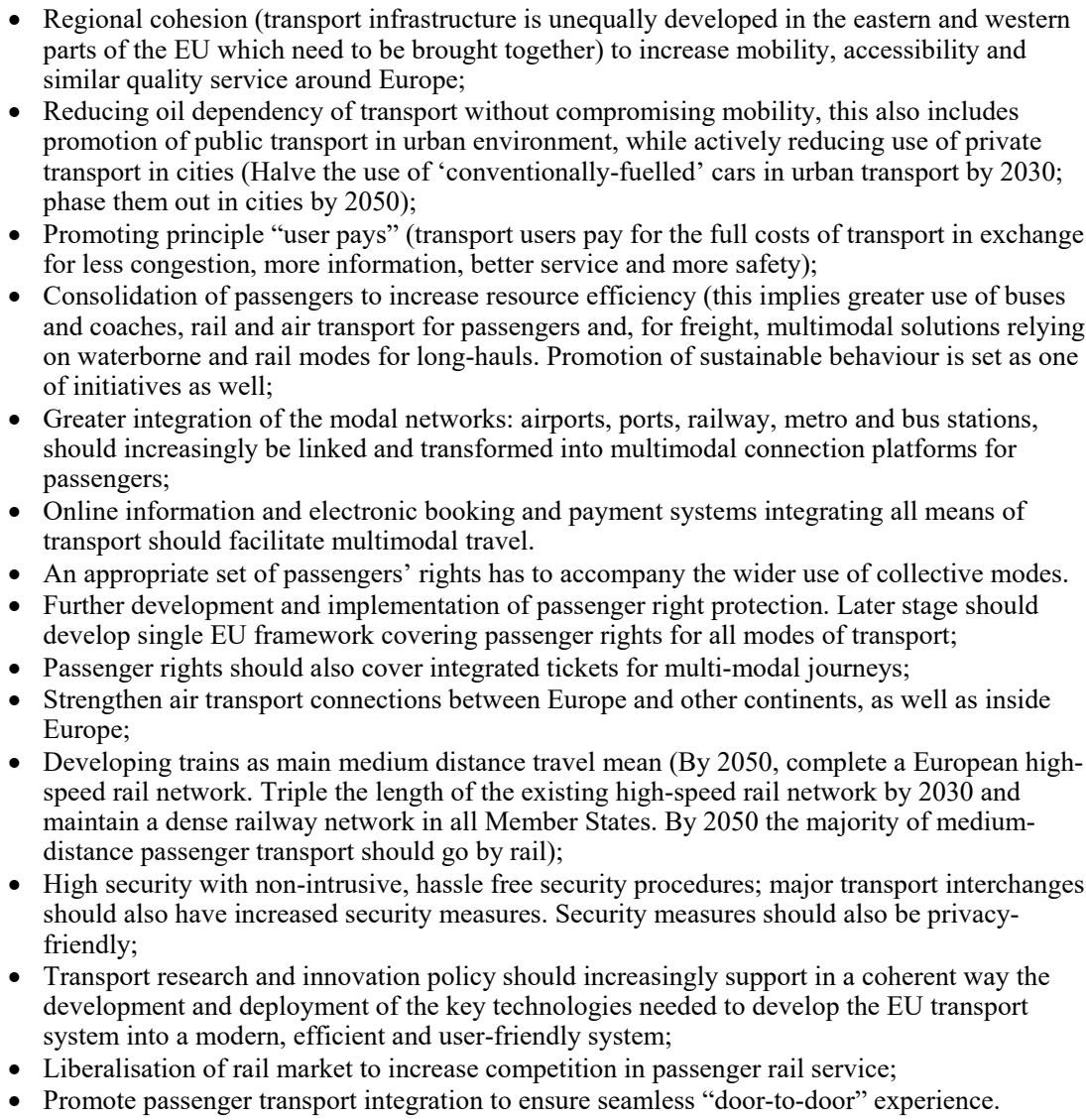 \\
\hline $\begin{array}{l}\text { Identified properties or } \\
\text { indicators }\end{array}$ & $\begin{array}{l}\text { - Safety; } \\
\text { - Main characteristics of service quality: } \\
\text { - Frequency of service; } \\
\text { - Easy access (accessibility); } \\
\text { - Reliability of services; } \\
\text { - Integration; } \\
\text { - Availability of information over travelling time (including information on alternative routing); } \\
\text { - Protection of passenger rights measures (including passenger right protection during crisis). }\end{array}$ \\
\hline
\end{tabular}

White paper 2011 continued previous passenger transport policy trends: integration, co-modality, information availability at all stages of journey and passenger right enforcement in all modes of transport.

This Communication provides more detailed insight on contents of passenger rights. Future vision is for passenger rights to equally cover all passenger transport modes with same transparency and similar policy on baggage, alternative routing in case of service disruption, costs reimbursement and accessibility. Evolution of the quality criteria in European transport policy documents is presented in Figure 2. The basic quality indicators are set in policy documents in the first Transport White Paper in 1992. It covers flexibility, speed, reliability, frequency, price, passenger rights protection and safety and security. Since 1998 there are new set of indicators related information, integration and accessibility. Since 2001 come territorial cohesion criteria, punctuality, transparency and reliability of information. The last set of indicators is related to environment impact, pollution, noise. 
Table 9. The most important aspects of Communication A European vision for Passengers: Communication on Passenger Rights in all transport modes

\begin{tabular}{|c|c|}
\hline Document name & $\begin{array}{l}\text { - Communication from the commission to the European } \\
\text { - Parliament and the council: A European vision for Passengers: } \\
\text { - Communication on Passenger Rights in all transport modes. }\end{array}$ \\
\hline $\begin{array}{l}\text { Most important aspects } \\
\text { regarding passenger transport }\end{array}$ & $\begin{array}{l}\text { - Passengers should expect a transport service that guarantees non-discrimination, assistance in } \\
\text { case of disruption of their journey, transparency of travel conditions, dignity of treatment and } \\
\text { full respect of the terms of their contract; } \\
\text { - Equal access to transport for all passengers disregarding their nationality, residence or } \\
\text { disability; } \\
\text { - Additional cost free assistance for disabled passengers in all modes of transport; } \\
\text { - Reimbursement of costs and provision of information on alternative travelling options in case } \\
\text { of disrupted service; }\end{array}$ \\
\hline $\begin{array}{l}\text { Identified properties or } \\
\text { indicators }\end{array}$ & $\begin{array}{l}\text { - Noise level; } \\
\text { - Pollution; } \\
\text { - Congestion; } \\
\text { - Transparency of information on pricing; } \\
\text { - Information and other help availability in case of disruption of transport service; } \\
\text { - Reimbursement of costs in case of disrupted service, damaged/lost baggage or injury. }\end{array}$ \\
\hline
\end{tabular}

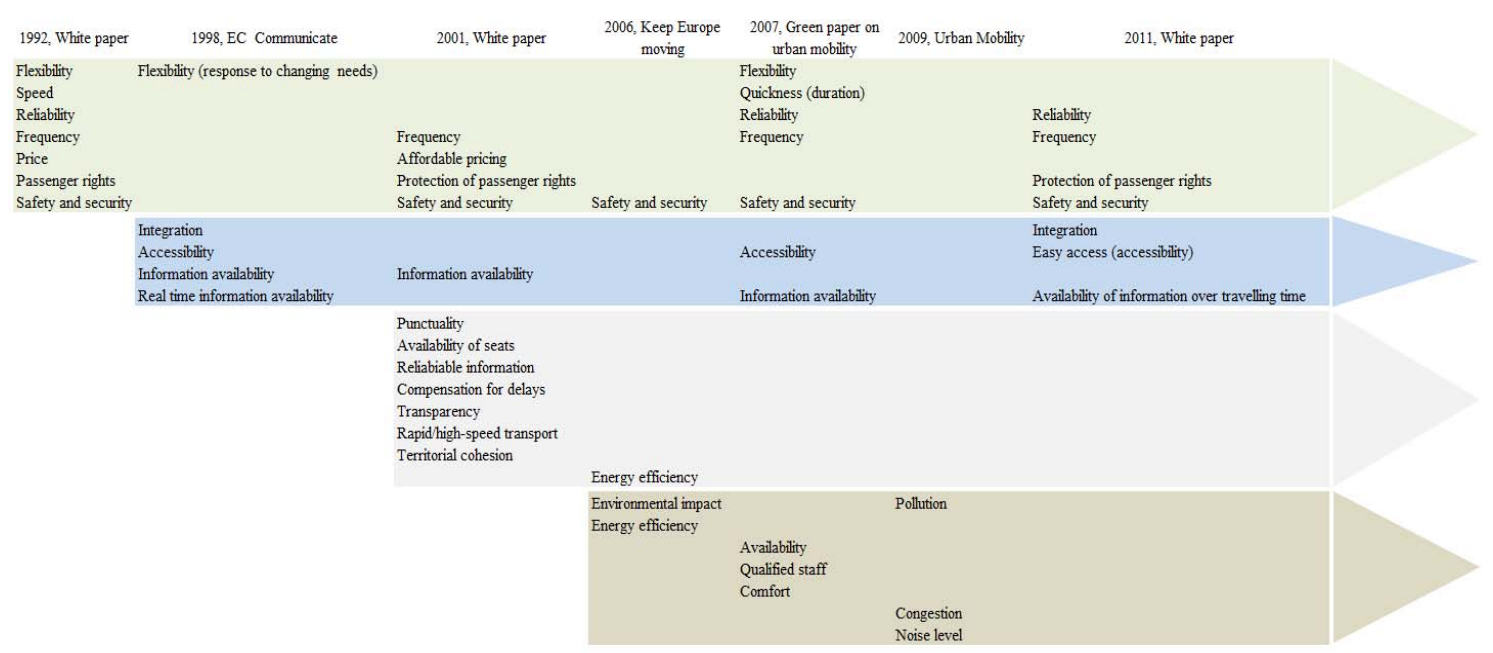

Figure 2. Evolution of the quality criteria in European transport policy documents

\subsection{Siauliai town case. Results of survey on travelling experience}

Car usage is the most popular transport mean in Siauliai (see Fig. 3).

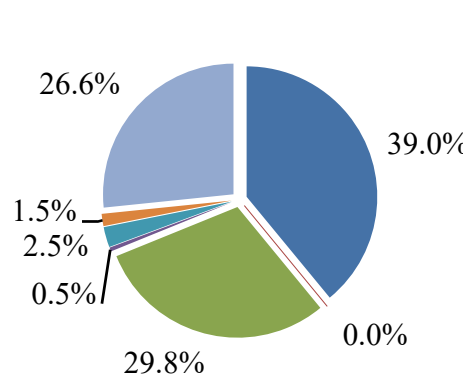

a) monthly average

car
motor-bike
bus
company/school
bus
taxi

taxi

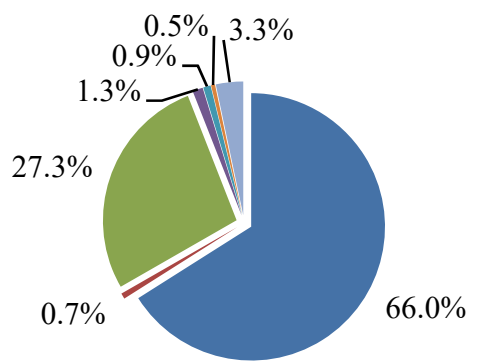

b) morning peak average

Figure 3. Modal shift in Siauliai town 
To compare the modal shift in the end 2016/ beginning 2017 to 2015 there is increase in car share. Moreover there is significant difference to compare weekly average and morning peak. The modal shift is caused the evaluation of mobility quality by different modes (Fig. 4).

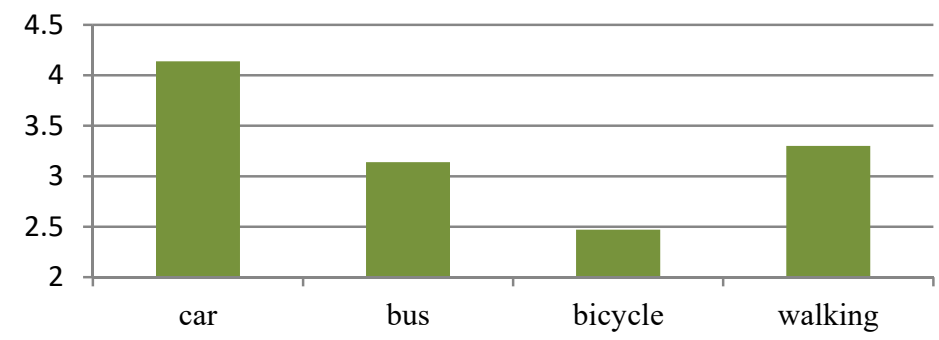

Figure 4. Evaluation of mobility quality by different modes (1 - poor, 5 - excellent)

The car travels are estimated as the best quality option as travels by bicycle are poorest. Even walking quality is perceived as better than bus or bicycle. Such kind traveller experience is caused by quality criteria and estimation based on those criteria. The main quality criteria's which is important for different modes are presented in figures below. The questions in questionnaire were formulated on basis "what criteria are most important to foster usage of transport mode".

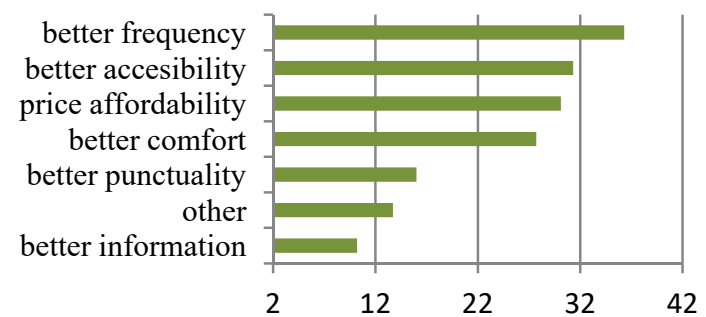

a) expectations for public transport

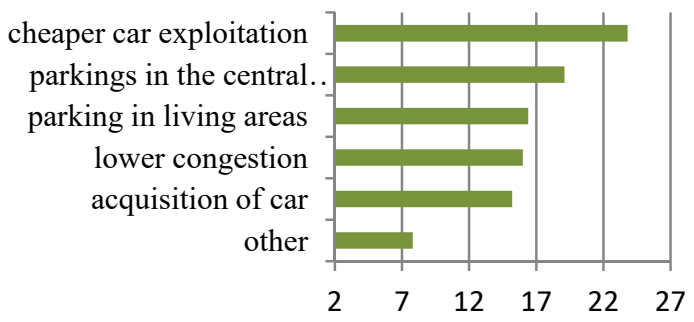

c) expectations for car usage

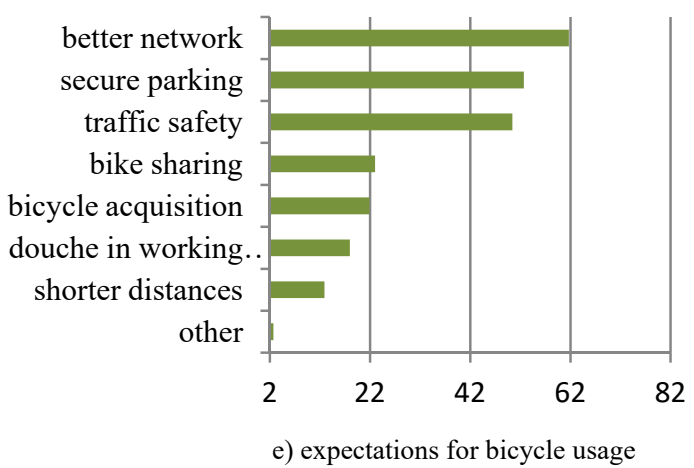

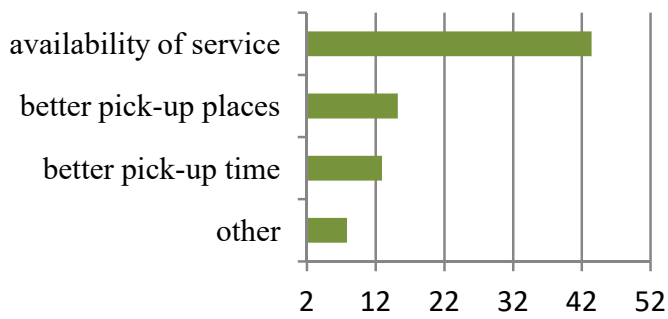

b) expectations for company/school bus services

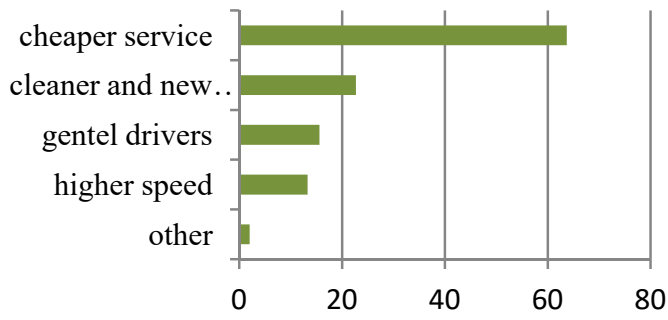

d) expectations for taxi

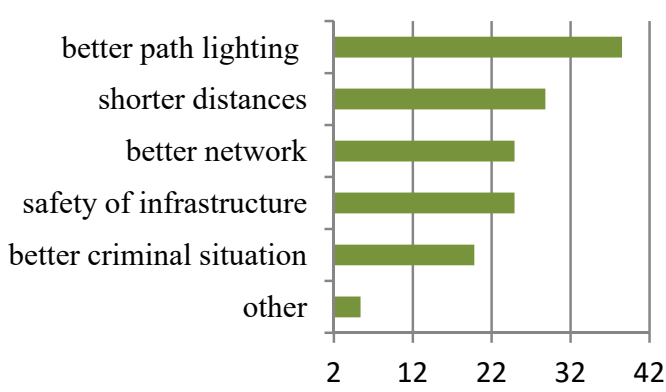

f) expectation for walking

Figure 5. Quality expectations for different modes of mobility (1 - low impact, 100 - high impact $)$ 
Summarizing the results of the survey (see Fig. 5) there is very close relations on modal shift and causes of such modal distribution. Fundamental and basic requirements for transport modes such as infrastructure, costs, safety and security, frequency of services remain as most important in Siauliai city.

\section{Conclusions and Discussion for Further Research}

The basic quality indicators are set in policy documents in the first Transport White Paper in 1992. It covers flexibility, speed, reliability, frequency, price, passenger rights protection and safety and security. Since 1998 there are new set of indicators related information, integration and accessibility. Since 2001 come territorial cohesion criteria, punctuality, transparency and reliability of information. The last set of indicators is related to environment impact, pollution and noise.

Survey of Siauliai inhabitants show, that the quality perception is mostly elated to such quality attributes such as infrastructure network (for bicycles and pedestrians), lighting of infrastructure, security and safety attributes, frequency of services, price affordability and accessibility. Those are basic passenger quality perception attributes defined in European documents $1992-2006$. However such attributes as energy efficiency, environment (pollution and noise) and congestion are not taken into account for Siauliai.

The article gives the example of policy measures inertia in relation to user attitude and perception. It counts approximately 10 years for Siauliai case. The further research is needed to compare inertia with other towns in the region and with other regions in Europe.

\section{Acknowledgements}

The research results of which presented in article was funded by the EU $7^{\text {th }}$ Framework Programme as part of the project A Measurement Tool to determine the quality of the Passenger Experience. Project number: FP7-SCP2-GA-2012-314354.

The survey of Siauliai town citizens is a part of sustainable urban mobility plan preparation and is funded by municipality of Siauliai town.

\section{References}

1. Action Plan on Urban Mobility (2009) Action Plan on Urban Mobility - State of Play.

2. Axtell, C.M., Hislop, D. and Whittaker, S. (2008) Mobile technologies in mobile spaces: Findings from the context of train travel. International Journal of Human-Computer Studies, 66(12), 902-915.

3. Carrasco, J.A., Miller, E.J. and Roorda, M.J. (2005) A tour-based model of travel mode choice. Transportation, 32, pp. 399-422.

4. Cavana, R.Y., Corbett, L.M. and Lo, Y.L. (2007) Developing zones of tolerance for managing passenger rail service quality. International Journal of Quality and Reliability Management, 24(1) 7-31.

5. Diana, M. and Daraio, C. (2013) Evaluating the effectiveness of public transport operations: a critical review and some policy indicators, submitted for publication.

6. Ettema, D., and Verschuren, L. (2007) The effect of multi-tasking on the value of travel time savings. Transportation Research Record, 2010, 19-25.

7. European Commission Communication (2006) Keep Europe moving - sustainable mobility for our Continent.

8. European Commission Communication (2009) A sustainable future for transport: Towards an integrated, technology-led and user.

9. European Commission Communication (2011) A European vision for Passengers: Communication on Passenger Rights in all transport modes.

10. European Commission Communication (1998) Developing the citizens network

11. Green paper (2007) Towards a new culture for urban mobility (presented by the Commission).

12. Guidelines. Developing and Implementing a Sustainable Urban Mobility Plan (2013) European Commission Communicate.

13. Hensher, D.A., Stopher, P. and Bullock, P. (2003) Service quality - developing a service quality index in the provision of commercial bus contracts. Transportation Research Part A, 37, 499-517.

14. Hess, S., Bierlaire, M. and Polak, J.W. (2005) Estimation of value of travel time savings using mixed logit models. Transportation Research Part A, 39, 221-236. 
15. Kahneman, D. (2000) Evaluation by moments: Past and future. In: D. Kahneman \& A. Tversky (Eds.), Choices, values, and frames. New York: Cambridge University Press, pp. 693-708.

16. Lyons, G., Jain, J. and Holley, D. (2007) The Use of Travel Time by Rail Passengers in Great Britain, Transportation Research Part A, 41, 107-120.

17. Pticina, I. (2011) The methodology of data collection about public transport service quality in Proceedings of the 11th International Conference "Reliability and Statistics in Transportation and Communication", Riga, Latvia.

18. Pticina, I., Yatskiv, I. (2105) Weighting the urban public transport system quality index (UPTQI) using the analytical hierarchy process", International Journal of Society Systems Science, Vol. 7, pp. 107-126.

19. Trompet, M., Parasram, R. and Anderson, R.J. (2013) Benchmarking disaggregate customer satisfaction scores between bus operators in different cities and countries, In: Proceeding of the Transportation Research Board 92th annual meeting, Washington DC.

20. White paper (1992) The future development of the common transport policy.

21. White paper (2001) European transport policy for 2010: time to decide.

22. White paper (2011) Roadmap to a Single European Transport Area - Towards a competitive and resource efficient transport system. 